Trinity University

Digital Commons @ Trinity

Geosciences Faculty Research

Geosciences Department

3-1982

\title{
Mineralogy and Phase Chemistry of Mount St. Helens Tephra Sets $W$ and $Y$ as Keys to Their Identification
}

Diane R. Smith

Trinity University, dsmith@trinity.edu

W. P. Leeman

Follow this and additional works at: https://digitalcommons.trinity.edu/geo_faculty

Part of the Earth Sciences Commons

\section{Repository Citation}

Smith, D.R. \& Leeman, W.P. (1982). Mineralogy and phase chemistry of Mount St. Helens tephra sets W and $Y$ as keys to their identification. Quaternary Research, 17(2), 211-227. doi:10.1016/ 0033-5894(82)90059-X

This Post-Print is brought to you for free and open access by the Geosciences Department at Digital Commons @ Trinity. It has been accepted for inclusion in Geosciences Faculty Research by an authorized administrator of Digital Commons@ Trinity. For more information, please contact jcostanz@trinity.edu. 


\section{Mineralogy and Phase Chemistry of Mount St. Helens Tephra Sets W and Y as Keys to Their Identification}

DIANE R. SMITH AND WILLIAM P. LEEMAN

Department of Geology, Rice University, Houston, Texas 77001

Received July 17, 1981

Voluminous and widespread tephras were produced frequently during the last 36,000 $\mathrm{yr}$ of volcanic activity at Mount St. Helens. Numerous tephra sets have been defined by D. R. Mullineaux, J. H. Hyde, and M. Rubin (1975, U.S. Geological Survey Journal of Research, 3, 329-335) on the basis of field relations, $\mathrm{Fe}-\mathrm{Mg}$ phenocryst assemblage, and ${ }^{14} \mathrm{C}$ chronology and are valuable marker beds for regional stratigraphic studies. In this study modal abundances and mineral compositions were determined (via petrographic and electron microprobe techniques) for numerous samples of individual layers within tephra sets $\mathrm{W}$ and $\mathrm{Y}$ to evaluate the degree of compositional variability within and between tephra layers and criteria by which to distinguish among Mount St. Helens and other Pacific Northwest tephras. Although individual layers within a set (e.g., We, Wn) cannot be distinguished from each other on the basis of mineralogic characteristics examined, mineral compositions allow distinction among layers W and Y and other Pacific Northwest tephras (e.g., Mazama, Glacier Peak). Fe-Ti oxide compositions and $\mathrm{T}-f_{02}$ estimates derived using coexisting magnetite-ilmenite are especially useful due to the compositional homogeneity of these minerals both within and between samples of a given unit over a wide geographic area. The silicates show more compositional variability than the oxides, but $\mathrm{SiO}_{2} / \mathrm{Al}_{2} \mathrm{O}_{3}$ contents in hornblende and $\mathrm{Fe} / \mathrm{Mg}$ ratios in hypersthene aid in distinguishing among Pacific Northwest tephras.

\section{INTRODUCTION}

The present-day cone and amphitheater of Mount St. Helens volcano are spatially associated with an ancestral volcanic center which came into existence at least 36,000 yr ago (Hyde, 1973; Mullineaux et $a l ., 1975)$. Since that time, eruptions of pumiceous tephras, pyroclastic flows, lavas, and domes were produced intermittently from the volcano. Detailed investigations of the eruptive history conducted previous to the 1980 eruptions have provided a time- stratigraphic framework for many of the eruptive products (Hopson, 1971; Hyde, 1973, 1975; Crandell and Mullineaux, 1973, 1978; Crandell et al., 1975; Mullineaux et a!., 1975; Hoblitt et al., 1980). A sequence of numerous tephra sets has been defined by Mullineaux et al. (1975) on the basis of field relations, ferromagnesian phenocryst 
assemblages, and ${ }^{14} \mathrm{C}$ geochronology (Fig. 1). Within each set there may be more than one layer of tephra, representing eruptions so closely spaced in time that no significant soil horizon developed between eruptions.

Many of the tephra layers are quite voluminous and widespread. Some layers (e.g., We, Wn) have thicknesses of $20 \mathrm{~cm}$ or more at distances of tens of kilometers from the volcano (Crandell and Mullineaux, 1978) and several layers have been traced as far as $900 \mathrm{~km}$ from the source (e.g., Westgate and Fulton, 1975; Smith et al., 1977; Westgate, 1977; Brewster and Barnett, 1979).

Due to their widespread distribution and their well-documented chronology, Mount St. Helens (MSH) tephras, when properly identified, are valuable marker beds for regional stratigraphic correlation and can be employed in a variety of geologic, archaeologic, and limnologic studies. MSH tephras are intercalated with tephras from other volcanic sources in the Pacific Northwest (e.g., Mount Mazama and Glacier Peak). Whereas tephras derived from different centers are usually distinguishable from one another, tephras erupted from the same center but at significantly different times may differ only slightly (Izett et a!., 1970, p. 121). As Westgate and Fulton noted (1975, p. 489), positive identification of distal portions of widespread airfall eruptive products may not be possible simply on the basis of field criteria such as coloration, degree of weathering, granulometry, thickness, and stratigraphic position. Detailed petrographic and compositional studies are necessary in order to distinguish and utilize individual MSH units in stratigraphic investigations.

It is necessary to evaluate the degree of homogeneity of individual MSH layers before mineralogic criteria can be used confidently in stratigraphic correlations of tephras. In this paper we report new mineralogical data, including modal abundances and mineral compositions, for two of the most voluminous silicic tephra sets, $\mathrm{W}$ and $\mathrm{Y}$. These data are used to estimate the inherent variability in mineralogical and compositional characteristics to be expected for these and other tephra units. As published mineralogic data for the MSH tephras are sparse, the data collected in this study will also provide a basis for petrogenetic studies and evaluation of eruptive mechanisms for the explosive silicic tephras. 


\section{PREVIOUS WORK}

Work toward characterization and identification of MSH tephras has involved identification of ferromagnesian silicate assemblages (Hyde, 1973; Mullineaux et al., 1975). The difficulty with this approach lies in the facts that the assemblages are repeated in successive MSH units (Fig. 1) and some are similar to those of tephra from other Cascade sources (Randle et al., 1971; Porter, 1978).

Other workers have characterized some of the tephras on the basis of elemental ratios in the glass as determined by electron microprobe (e.g., Smith and Westgate, 1969; Okazaki et al., 1972; Smith et al., 1977). Figure 2 illustrates Ca-Fe-K ratios for Glacier Peak tephra, the climactic eruption of Mount Mazama, Bridge River tephra, and numerous MSH tephras. On this basis one can readily distinguish among Glacier Peak, Mazama, Bridge River, and several MSH tephras; however, differences between some MSH tephras are not very great and individual eruptions within a set cannot always be distinguished (e.g., Ye and Yn). The effectiveness of this method may be lessened when applied to older units due to alteration or leaching of the glasses which is commonly accompanied by depletion of alkalies (Lipman, 1965).

Small differences in trace element abundances in glass and mineral separates have allowed successful discrimination of certain units (Dudas et al., 1973; Randle et al., 1971; Sarna-Wojcicki et al., 1980). However, this requires preparation of pure fractions (not always feasible), and possible compositional zoning within individual tephra layers has not been evaluated.

Scanning electron microprobe studies of glass shards have been made for tephra layers We and Wn to define morphologic characteristics (Smith et al., 1977). No distinguishing morphology for pumice lumps of lapilli size were observed, but these units could be differentiated on the basis of morphological characteristics of ash-size glass shards from more than $200 \mathrm{~km}$ from the volcano.

Westgate and his colleagues (Westgate and Fulton, 1975; Westgate et al., 1977; Westgate and Evans, 1978; Brewster and Barnett, 1979; Mathewes and Westgate, 1980) have recognized the effectiveness of iron-titanium oxide composition as a tool in distinguishing tephras in the plains of southwestern Canada. Their investigations include units which they believe to be the distal portions of tephras from MSH on the basis of several criteria. However, no systematic detailed characterization has been performed on individual layers near the volcano where stratigraphic relations can be discerned unambiguously from field criteria. 


\section{METHODS OF STUDY}

\section{Sampling}

Tephra sets $\mathrm{W}$ and $\mathrm{Y}$ are each composed of several layers of pumice lapilli which represent separate eruptions and are distinguishable near the volcano. The initial sampling was carried out in the fall of 1977 with the assistance of D. R. Mullineaux. Sampling was completed in the summer of 1978. For this study, samples of layers We, Wn, Ye, and Yn were taken from numerous localities within each layer (Fig. 3 and Table 1). At a few localities samples were collected at different horizons within a given tephra layer. Only crystal-rich pumice clasts were sampled because these are clearly magmatic products that record preeruptive conditions in the chamber(s) and because the effects of crystal winnowing and/or contamination are minimized.

\section{Analytical Methods}

Heavy-mineral separates were examined by standard petrographic techniques to determine the mineral assemblage and modal abundances. Chemical analyses of the heavy minerals, as well as plagioclases, were determined by use of an ETEC electron microprobe with both natural and synthetic mineral standards. Either 15 or $20 \mathrm{kV}$ emission current, 0.025 current, 20 -sec counting periods, and $1-\mu \mathrm{m}$ electron beam-diameter were routine operating conditions. Rim and core analyses were performed to check for zoning and overall homogeneity. Raw data were corrected for dead time of detectors, instrument current drift, spectrometer background and matrix (ZAF) effects using the computer program PROBEG. Accuracy is estimated to be no worse than $2 \%$ for major elements and $5-10 \%$ for minor elements, on the basis of replicate microprobe analyses compared with wet chemical analyses of the standards.

\section{RESULTS}

\section{Modal Abundances}

Results of modal analyses of the heavy-mineral separates are listed in Table 2. Figure 4 illustrates hypersthene-hornblende-Fe-Ti oxide proportions for units $\mathrm{We}$ and $\mathrm{Wn}$, and cummingtonite-hornblendeFe-Ti oxide proportions for units Ye and Yn. Unit Y shows a large range in modes, mostly due to variations in contents of the oxide minerals, whereas $\mathrm{W}$ is more uniform. Layers examined within $\mathrm{W}$ are indistinguishable, and layers Ye and Yn are only marginally distinct. 


\section{Electron Microprobe Studies}

Plagioclases in layers of $\mathrm{W}$ and $\mathrm{Y}$ exhibit a large compositional range within each layer (Fig. 5), the total range being $\mathrm{An}_{35-85}$. Oscillatory, normal, and reverse zoning were observed. Neither core compositions nor zoning patterns were distinctive for sets $\mathrm{W}$ and $\mathrm{Y}$ and layers within $\mathrm{W}$ and $\mathrm{Y}$. No correlation of composition with stratigraphic position was evident.

Table 3 presents representative analyses of orthopyroxene from samples of We and Wn (orthopyroxene was not observed in set $\mathrm{Y}$ ) and compositional ranges for the two layers are illustrated in Figure 6. The range of composition is not large $\left(\sim \mathrm{En}_{50-60}\right)$ and there is no relation between stratigraphic position and composition of the hypersthene. Rims of some of the analyzed grains are slightly more magnesian $\left(E n_{57}\right)$ relative to the cores $\left(E_{54}\right)$. In comparison, orthopyroxene in Glacier Peak tephra has a higher enstatite component ( $\mathrm{En}_{65-66}$ (Westgate and Evans, 1978); Fig. 6).

Cummingtonite is present in layers $\mathrm{Ye}$ and $\mathrm{Yn}$ as discrete prismatic phenocrysts and as cores of grains rimmed by hornblende. Discrete grains and cores of zoned grains were analyzed, and Table 4 lists representative analyses; compositional ranges are shown in Figure 6. Most grains analyzed are compositionally homogeneous, but a few of the discrete grains within Ye were found to have more magnesian rims (see analyses for sample SH-17, Table 4). The range in composition is rather limited $(\sim 10$ mole $\%)$ and is overlapping between the two layers. No correlation was observed between composition and mode of textural occurrence.

Hornblende occurs in both sets $\mathrm{W}$ and $\mathrm{Y}$ and was analyzed in each layer examined (see Table 5 for representative analyses). Within a given layer, the amphibole exhibits a large range in composition. In fact, the entire range of composition was observed not only in samples collected from different localities of a given unit, but even within single pumice clasts. $\mathrm{Ca}-\mathrm{Fe}-\mathrm{Mg}$ diagrams show the overlapping but small range ( 10 mole\%) of these components in different tephra units (Fig. 6). On the basis of $\mathrm{SiO}_{2}$ and $\mathrm{Al}_{2} \mathrm{O}_{3}$ contents in hornblendes one can distinguish set $\mathrm{W}$ from set $\mathrm{Y}$, but only marginally Glacier Peak tephra (Fig. 7). Layers examined within a given tephra set cannot be distinguished from each other (e.g., We and Wn). Hornblende in MSH layer Y is indistinguishable from hornblende in Glacier Peark tephra, but the presence of cummingtonite in $\mathrm{Y}$ and its absence in Glacier Peak tephra aid in proper identification. 
Iron-titanium oxides occur as micro-phenocrysts and as inclusions within silicate phenocrysts in all the tephras studied. The oxides were not observed to exhibit exsolution or oxidation characteristics. Analyses were recalculated according to the method of Carmichael (1967) to estimate stoichiometric contents of $\mathrm{FeO}$ and $\mathrm{Fe}_{2} \mathrm{O}_{3}$. The ülvospinel content of the titanomagnetite and hematite content of the ilmenite solid solutions were calculated from these adjusted analyses. The results are listed in Table 6 (see the Appendix for a complete listing of analyses for individual MSH samples). The analyses of Fe-Ti oxides in Ye and Yn of this study are similar to reported analyses of these minerals in distal MSH "Y" (Table 7). The exceptions are small differences in $\mathrm{MgO}$ content in ilmenite and calculated $\mathrm{FeO}$ and $\mathrm{Fe}_{2} \mathrm{O}_{3}$ (assuming stoichiometry), which could be due to use of different standards and techniques.

In contrast to the silicates, titanomagnetite and ilmenite grains in MSH tephra layers are compositionally homogeneous whether they occur as phenocrysts or as inclusions within other minerals. Furthermore, these phases are compositionally distinctive between different tephra sets. Differences in $\mathrm{MgO}, \mathrm{Al}_{2} \mathrm{O}_{3}$, and $\mathrm{TiO}_{2}$ contents in titanomagnetite allow distinction of tephra sets $\mathrm{Y}$ and $\mathrm{W}$ from each other and from other Pacific Northwest tephras, but not layer Ye from Yn nor layer We from Wn (Figs. 8a and b). Likewise, $\mathrm{TiO}_{2}$ content in ilmenite is a useful discriminator.

\section{Temperature-Oxygen Fugacity Estimates}

Differences in preemptive physical conditions may have existed for different tephras. The compositional data were utilized in estimating temperatures and oxygen fugacities of equilibration of coexisting oxides using the method of Buddington and Lindsley (1964) to ascertain whether the values would allow distinction of tephras. The results for average compositions of Fe-Ti oxides are included in Table 6.

Samples of tephra set W collected from different localities give a small spread of Fe-Ti oxide composition which in tum implies a temperature range of $810-833^{\circ} \mathrm{C}$ and a $-\log f_{\mathrm{O}_{2}}$ range of $12.7-13.3$ for layer $\mathrm{Wn}$ and $821-848^{\circ} \mathrm{C}$ and 12.9-13.0 for layer We. Considering the precision of the geothermometer and geobarometer, there is no correlation between $\mathrm{T}, f_{\mathrm{O}_{2}}$, and stratigraphic level within $\mathrm{W}$ tephra. Data for tephra set $\mathrm{Y}$ also yield a small range of temperature and $-\log f_{\mathrm{O}_{2}}$ of 860 $884^{\circ} \mathrm{C}$ and 10.6-11.1, respectively. 
Difficulties arise in comparing the temperatures and oxygen fugacities calculated in this study to temperatures and oxygen fugacities calculated for other Pacific Northwest tephras using published FeTi oxides analyses, due to differences in $\mathrm{FeO}$ and $\mathrm{Fe}_{2} \mathrm{O}_{3}$ calculations as mentioned previously. Thus, published $\mathrm{FeO}$ and $\mathrm{Fe}_{2} \mathrm{O}_{3}$ contents were recalculated to total $\mathrm{FeO}$ (where total $\mathrm{FeO}=\left(0.9 \times \mathrm{Fe}_{2} \mathrm{O}_{3}\right)+$ $\mathrm{FeO}$ ). $\mathrm{FeO}$ and $\mathrm{Fe}_{2} \mathrm{O}_{3}$ contents were then determined in the same manner as for analyses of this study. The resulting values and calculated ülvospinel and hematite contents (mole percentage, determined in the same manner as for analyses of this study) are included in Table 7. Temperatures and oxygen fugacities calculated using the data are listed in Table 7 and plotted in Figure 9 along with average temperatures and oxygen fugacities calculated for MSH tephras. Published analyses of MSH "Y"

oxides give $T-f_{\mathrm{O}_{2}}$ values very close to the range found using analyses of this study. With the exception of Glacier Peak and Mazama tephras, it appears possible to distinguish several Pacific Northwest tephras, including sets from Mount St. Helens, on this basis. It was not possible to distinguish between individual layers within MSH sets W and Y.

\section{DISCUSSION AND CONCLUSIONS}

Near-source samples of Mount St. Helens tephra set W are readily distinguished from set $\mathrm{Y}$ on the basis of their mineralogic characteristics, but within these sets, individual layers cannot be distinguished from each other on the basis of mineralogy and phase chemistry. No single characteristic is in itself the key to distinguishing among individual Pacific Northwest tephras. Within the constraints of field relations and available ${ }^{14} \mathrm{C}$ ages, the most distinctive parameters are phenocryst assemblage, ferromagnesian phenocryst composition, composition of iron-titanium oxides, and calculated temperature and oxygen fugacity estimates based on compositions of coexisting magnetite and ilmenite. Table 8 summarizes some of the characteristics useful in tephra identification.

Possibly the most effective technique in tephra distinction is identification of ferromagnesian silicate assemblages augmented, where necessary, by analyses of iron-titanium oxides. Glass-encased magnetite and ilmenite grains are commonly found in downwind tephra deposits and are considerably easier to analyze than glass shards. Also, we have found the Fe-Ti oxide minerals to be remarkably homogeneous both within and between samples of a given unit over a wide geographic area. Analysis of glasses may be complicated by volatilization of alkalies (especially sodium) and very fine-grained, vesicular shards. These problems and possible posteruption alteration may hinder correct identification of tephras on the basis of glass chemistry, especially where only small chemical differences exist for tephras erupted from the same volcanic center. 
Distinction of tephras on the basis of iron-titanium oxide composition is dependent on precise determination of the minor elements. Differences in analyses made in different laboratories may result from the use of different standards, operating conditions, and data reduction methods. Thus, in order to apply the techniques used here effectively and to facilitate interlaboratory comparison, it is advised that samples of proximal tephras known to be from a specific unit (e.g., W, Y) be analyzed as "'internal standards".

Work in progress includes characterization of other proximal and distal Mount St. Helens tephras (sets T, S, P, J, M, K, C), including mineral compositions, glass chemistry, and geothermometry and geobarometry.

\section{APPENDIX}

The following is a list of iron-titanium oxide compositions for samples of tephra sets $\mathrm{W}$ and $\mathrm{Y}$. The mean for $n$ (number of) analyses is given, with the standard deviation in parentheses. 
Titaromanocettre Compostronas

\begin{tabular}{|c|c|c|c|c|c|}
\hline $\begin{array}{r}\text { Unit: } \\
\text { Sample: }\end{array}$ & $\begin{array}{c}\text { Wn } \\
\text { DS-11 }\end{array}$ & $\begin{array}{c}\text { Wn } \\
\text { DS-40 }\end{array}$ & $\begin{array}{c}\text { Wn } \\
\text { DS-45 }\end{array}$ & $\begin{array}{c}\text { Wn } \\
\text { DS-50 }\end{array}$ & $\begin{array}{c}W_{n} \\
\text { DS-51 }\end{array}$ \\
\hline $\mathrm{SiO}_{2}$ & $0.22(0.03)$ & $0.23(0.08)$ & $0.17(0.07)$ & $0.23(0.08)$ & $0.24(0.04)$ \\
\hline $\mathrm{TiO}_{2}$ & $9.63(0.16)$ & $9.66(0.17)$ & $9.66(0.13)$ & $9.82(0.77)$ & $9.78(0.12)$ \\
\hline $\mathrm{Al}_{2} \mathrm{O}_{2}$ & $2.39(0.09)$ & $2.48(0.03)$ & $2.42(0.04)$ & $2.43(0.09)$ & $2.31(0.14)$ \\
\hline $\mathrm{FeO}$ & $38.1 \quad(0.10)$ & $37.7 \quad(0.03)$ & $37.9 \quad(0.20)$ & $38.3 \quad(0.06)$ & $38.2(0.15)$ \\
\hline $\mathrm{Fe}_{2} \mathrm{O}_{2}$ & $46.5 \quad(0.12)$ & $46.5 \quad(0.04)$ & $46.1 \quad(0.24\rangle$ & $45.6 \quad(0.10)$ & $45.7 \quad(0.18)$ \\
\hline $\mathrm{MnO}$ & $0.32(0.03)$ & $0.36(0.03)$ & $0.33(0.02)$ & $0.38(0.02)$ & $0.36(0.03)$ \\
\hline $\mathrm{MgO}$ & $1.16\{0.05\rangle$ & $1.42(0.48)$ & $1.13(0.12)$ & $1.01(0.17)$ & $1.08(0.11)$ \\
\hline Sum & 98.32 & 98.35 & 97.71 & 97.79 & 98.87 \\
\hline n & 5 & 5 & 5 & 4 & 5 \\
\hline Unit: & $w_{n}$ & $W n$ & We & We & We \\
\hline Sample: & DS-57 & DS- 60 & DS-19 & DS-30 & DS -47 \\
\hline $\mathrm{SiO}_{2}$ & $0.26(0.08)$ & $0.26(0.03)$ & $0.26(0.04)$ & $0.25(0.09)$ & $0.25(0.04)$ \\
\hline $\mathrm{TiO}_{2}$ & $9.63(0.07)$ & $9.78(0.24)$ & $9.54(0.18)$ & $9.78(0.15)$ & $9.66(0.11)$ \\
\hline $\mathrm{Al}_{2} \mathrm{U}_{5}$ & $2.36\langle 0.19\rangle$ & $2.41(0.07)$ & $2.09(0.109)$ & $2.09(0.12)$ & $2.12\langle 0,(5)\}$ \\
\hline $\mathrm{FeO}$ & $38.0(0.17)$ & $39.5 \quad(0.07)$ & $37.7 \quad(0.03)$ & $37.6 \quad(0.16)$ & $37.6(0.09)$ \\
\hline $\mathrm{Fe}_{2} \mathrm{O}_{z}$ & $45.7 \quad(0.21)$ & $43.7 \quad(0.08)$ & $46.9 \quad(0.04)$ & $46.3 \quad(0.19)$ & $46.3(0.12)$ \\
\hline $\mathrm{MnO}$ & $0.34(0.02)$ & $0.38(0.01)$ & $0.34(0.0-4)$ & $0.38(0.01)$ & $0.35(0.04)$ \\
\hline $\mathrm{MgO}$ & $1.01(0.10)$ & $1.01(0.19)$ & $1.30(0.07)$ & $1.40(0.16)$ & $1.31<0.03)$ \\
\hline Sum & 97.31 & 97,04 & 98.13 & 97.80 & 97.59 \\
\hline$n$ & 5 & 4 & 4 & 5 & 5 \\
\hline Unit: & We & $\mathrm{We}$ & $\mathrm{Yn}_{\mathrm{n}}$ & $\mathrm{Y}_{\mathrm{n}}$ & $Y_{n}$ \\
\hline Sample: & ns-ร5 & $\mathrm{SH}-1 \mathrm{~K}$ & DS-5K & DS-13 & $128-54$ \\
\hline $\mathrm{SiO}_{2}$ & $0.21\langle 0.03\rangle$ & 0.20 & $0.11(0.04)$ & $0.12(0.03)$ & $0.15(0.04)$ \\
\hline $\mathrm{TOO}_{2}$ & $9.66(0.24)$ & 9.78 & $5.62(0.31)$ & $5.68(0.25)$ & $5.48(0.18)$ \\
\hline $\mathrm{Al}_{2} \mathrm{O}_{\mathrm{D}}$ & $2.07(0.40\rangle$ & 1.84 & 2.35 (0.08) & $2.68(0.10)$ & $2.76(0.06)$ \\
\hline $\mathrm{FeO}$ & $37.8(0.13)$ & 38.4 & $34.1 \quad(0.24)$ & $34.4(0.10)$ & $33.8 \quad(0.11)$ \\
\hline $\mathrm{Fe}_{2} \mathrm{O}_{3}$ & $46.2(0.16)$ & 47.2 & $54.3 \quad(0.39)$ & $54.2(0.15)$ & $54.2(0.18)$ \\
\hline Mno & $0.37(0.03)$ & 0.35 & $0.30(0.02)$ & $0.33(0.02)$ & $0.36(0.04)$ \\
\hline $\mathrm{MgO}$ & $1.10(0.12)$ & 1.02 & $1.24(0.24)$ & $1.17(0.13)$ & $1.33(0.14)$ \\
\hline Sum & 97.41 & 98.79 & 98.22 & 98.58 & 98.08 \\
\hline$n$ & 5 & 1 & 5 & 5 & 5 \\
\hline $\begin{array}{l}\text { Unit: } \\
\text { Sample: }\end{array}$ & $\underset{\mathrm{Yn}}{\mathrm{Yn} .44}$ & $\begin{array}{c}\mathrm{Ye} \\
\text { DS-86 }\end{array}$ & $\begin{array}{c}Y e \\
D S-48\end{array}$ & $\begin{array}{c}Y_{\mathrm{e}} \\
\text { DS-31 }\end{array}$ & $\begin{array}{c}\text { Ye } \\
\text { DS-36 }\end{array}$ \\
\hline $\mathrm{SiO}_{2}$ & $0.11(0.02)$ & $0.11(0,02)$ & $0.13(0.05)$ & $0.12(0.03)$ & $0.14(0.04)$ \\
\hline $\mathrm{TiO}_{2}$ & $5.52(0.18)$ & $5.84(0.13)$ & $5.80(0.26)$ & $5.74(0.11)$ & $5.81(0.32)$ \\
\hline $\mathrm{Al}_{2} \mathrm{O}_{2}$ & $2.83(0.12)$ & $2.67(0.13)$ & $2.80(0.10)$ & $2.72(0.11)$ & $2.71(0.11)$ \\
\hline $\mathrm{FeO}$ & $34.3\langle 0.27\rangle$ & $34.0 \quad(0.16)$ & $33.9(0.26)$ & $34.3 \quad(0.13)$ & $34.5\langle 0.27\rangle$ \\
\hline $\mathrm{Fe}_{2} \mathrm{O}_{3}$ & $55.2(0.44)$ & $53.6 \quad(0.25)$ & $53.5 \quad(0.41)$ & $54.1(0.21)$ & $54.0(0.42)$ \\
\hline MnO & $0.30(0.03)$ & $0.33(0.02)$ & $0.35(0.02)$ & $0.36(0.01)$ & $0.36\{0.03\}$ \\
\hline $\mathrm{MgO}$ & $1.33(0.12)$ & $1.38(0.18)$ & $1.41(0.06)$ & $1.24(0.14)$ & $1.20(0.04)$ \\
\hline Sum & 99.65 & 97.93 & 97.89 & 98.58 & 98.72 \\
\hline \multirow[t]{2}{*}{$\pi$} & 4 & 4 & 5 & 5 & 5 \\
\hline & $\begin{array}{l}\text { Unit: } \\
\text { Sample- }\end{array}$ & $\begin{array}{c}\mathrm{Ye} \\
\mathrm{nS}-5 ?\end{array}$ & $\begin{array}{c}\mathrm{Ye} \\
\mathrm{DS}-\mathrm{n}\end{array}$ & & $\begin{array}{c}\mathrm{Ye} \\
\text { DS.38 }\end{array}$ \\
\hline $\mathrm{SiO}_{2}$ & & $0.11(0.04)$ & $0.10(0.03)$ & & $0.12(0.04)$ \\
\hline $\mathrm{TiO}_{2}$ & & $5.80(0.40)$ & $5.85(0.19)$ & & $5.69(0.11)$ \\
\hline $\mathrm{Al}_{2} \mathrm{U}_{3}$ & & $2.95(0.57)$ & $2.74\langle 0.12\rangle$ & & $2.72(0.14)$ \\
\hline $\mathrm{FeO}$ & & $34.4 \quad(0.24)$ & $34.6(0.17)$ & & $34.3 \quad(0.19)$ \\
\hline $\mathrm{Fe}_{2} \mathrm{O}_{2}$ & & $53.9 \quad(0.38)$ & $54.5 \quad(0.26)$ & & $54.1 \quad(0.29)$ \\
\hline $\mathrm{MaO}$ & & $0.36(0.02)$ & $0.36(0.02)$ & & $0.36(0.02)$ \\
\hline $\mathrm{MgO}$ & & $1.26(0.05)$ & $1.24(0.11)$ & & $1.20(0.12)$ \\
\hline Sum & & 98.78 & 99.39 & & 98.49 \\
\hline$n$ & & 5 & 5 & & 4 \\
\hline
\end{tabular}


I.MentTe Cosmositrons

\begin{tabular}{|c|c|c|c|c|}
\hline $\begin{array}{l}\text { Unit: } \\
\text { Sample: }\end{array}$ & $\begin{array}{c}\text { Wn } \\
\text { DS-11 }\end{array}$ & $\begin{array}{c}W n \\
D S-40\end{array}$ & $\begin{array}{c}\text { Wn } \\
\text { DS-4S }\end{array}$ & $\begin{array}{c}\mathrm{W}_{\mathrm{B}} \\
\mathrm{DS}-51\end{array}$ \\
\hline $\mathrm{siO}$ & $0.24(0.06)$ & $0.23(0.06)$ & $0.18\{0.03\rangle$ & $0.14(0.06)$ \\
\hline $\mathrm{TiO}_{2}$ & $44.6 \quad\{0.60\rangle$ & $44.7 \quad(0.65)$ & $45.2(0.31)$ & $45.1 \quad(0.24)$ \\
\hline $\mathrm{Al}_{3} \mathrm{O}$ & $0.02(0.02)$ & $\mathrm{tr}^{\mathrm{r}}$ & tr & tf \\
\hline $\mathrm{FeO}$ & $37.5 \quad(0.12)$ & $37.1 \quad(0.16)$ & $37.7\langle 0.26\rangle$ & $37.2(0.24)$ \\
\hline $\mathrm{Fe}_{2} \mathrm{O}_{3}$ & $13.3(0.04)$ & $13.9(0.06)$ & $13.6(0.09)$ & $14.0(0.09)$ \\
\hline $\mathrm{MnO}$ & $0.48(0.01)$ & $0.48(0.03)$ & $0.51(0.05)$ & $0.48(0.04)$ \\
\hline $\mathrm{MgO}$ & $1.39(0.24)$ & $1.62(0.17)$ & $1.49(0.17)$ & $1.71(0.18)$ \\
\hline Sum & 97.53 & 98.03 & 98.68 & 98.63 \\
\hline A & 5 & 5 & 5 & 5 \\
\hline Unit: & Wn & We & We & We \\
\hline Sample: & DS. 60 & DS-19 & DS-30 & DS-47 \\
\hline $3 i O_{i}$ & $0.20(0.09)$ & $0.18(0.09)$ & $0.12(0.04)$ & $0.27(0.08)$ \\
\hline $\mathrm{TiO}_{2}$ & $44.8 \quad(0.33)$ & $44.8 \quad(0.38)$ & $44.8 \quad(1.03)$ & $45.2\langle 0.43\rangle$ \\
\hline $\mathrm{Al}_{2} \mathrm{O}_{3}$ & $0.08(0.06)$ & tr & tr & tr \\
\hline $\mathrm{FeO}$ & $37.1 \quad(0.27)$ & $36.9 \quad(0.17)$ & $36.5\langle 0.17\rangle$ & $37.1\langle 0.20\rangle$ \\
\hline $\mathrm{Fe}_{2} \mathrm{O}_{3}$ & $13.7 \quad(0.10)$ & $13.8 \quad(0.06)$ & $13.9(0.07)$ & $13.9(0.08)$ \\
\hline $\mathrm{MnO}$ & $0.48(0.02)$ & $0.50(0.03)$ & $0.50(0.02)$ & $0.51(0.03)$ \\
\hline $\mathrm{M} \nsubseteq \mathrm{O}$ & $1.70(0.20)$ & $1.78(0.15)$ & $1.64\langle 0.09\rangle$ & 1. $\mathrm{RR}\langle 0.17\rangle$ \\
\hline Sum & 98.09 & 97.96 & 97.46 & 98.86 \\
\hline$n$ & 4 & 5 & 4 & 5 \\
\hline $\begin{array}{r}\text { Unit: } \\
\text { Sample: }\end{array}$ & $\begin{array}{c}\text { We } \\
\text { DS-55 }\end{array}$ & $\begin{array}{c}\text { We } \\
\text { SH-18 }\end{array}$ & $\mathrm{Yn}^{6}$ & $\mathrm{Ye}^{\prime}$ \\
\hline $\mathrm{SiO}_{2}$ & $0.17(0.10)$ & 0.19 & $0.17(0.06)$ & $0.21(0.11)$ \\
\hline $\mathrm{TiO}_{2}$ & $44.7 \quad(0.26)$ & 44.7 & $39.9(0.7)$ & $39.3<1.2\rangle$ \\
\hline $\mathrm{Al}_{f} \mathrm{O}_{3}$ & $\mathrm{tr}$ & 0.06 & $0.25(0.11)$ & $0.33(0.14)$ \\
\hline $\mathrm{FeO}$ & $36.4\{0.21\}$ & 36.3 & $32.1<0.4)$ & $31.4(0.5)$ \\
\hline $\mathrm{Fe}_{2} \mathrm{O}_{3}$ & $14.4 \quad(0.03)$ & 15.9 & $24.2 \quad(0.3)$ & $24.9(0.4)$ \\
\hline $\mathrm{MnO}$ & $0.52(0.03)$ & 0.53 & $0.48(0,03)$ & $0.46(0.04)$ \\
\hline $\mathrm{M}_{\mp} \mathrm{O}$ & $1.94(0.07)$ & 2.00 & $1.98\langle 0.25\}$ & $2.00(0.38)$ \\
\hline Sum & 98.13 & 99.68 & 99.08 & 98.69 \\
\hline$n$ & 4 & 1 & 6 & 8 \\
\hline
\end{tabular}

* Ir m trace amount

"Represents an average of $n$ analyses performed on several random samples of the tephra layer.

\section{ACKNOWLEDGMENTS}

This work was supported by funds from the National Science Foundation (Grant EAR79-19998 to W. P. Leeman) and a Penrose Research grant from the Geological Society of America (to D. R. Smith). Information on tephra localities critical to this study was generously supplied by Dr. D. R. Mullineaux, U.S. Geological Survey at Denver, Colorado. Mr. Randy Hermens, Portland, Oregon, kindly assisted in the field and Ms. Linda Peyton, Rice University, Houston, Texas, assisted in preparation of mineral separates. 


\section{REFERENCES}

Brewster, G. R., and Barnett, R. L. (1979). Magnetites from a new unidentified tephra source, Banff National Park, Alberta. Canadian Journal of Earth Sciences 16, 1294-1297.

Buddington, A. F., and Lindsley, D. H. (1964). Iron-titanium oxide minerals and synthetic equivalents. Journal of Petrology 5, 3!0-357.

Carmichael, I. S. E. (1967). The iron-titanium oxides of salic volcanic rocks and their associated ferromagnesian silicates. Contributions to Mineralogy and Petrology 14, 36-64.

Crandell, D. R. (1971). "Postglacial Lahars from Mount Rainier Volcano, Washington." U.S. Geological Survey Professional Paper 677.

Crandell, D. R., and Mullineaux, D. R. (1973). "Pine Creek Volcanic Assemblage at Mount St. Helens, Washington." U.S. Geological Survey Bulletin 1383-A.

Crandell, D. R., and Mullineaux, D. R. (1978). "Potential Hazards from Future Eruptions of Mount St. Helens Volcano, Washington." U.S. Geological Survey Bulletin 1383-C.

Crandell, D. R., Mullineaux, D. R., and Rubin, M. (1975). Mount St. Helens: Recent and future behavior. Science 187, 438-441.

Dudas. M. J., Harward, M. D., and Schmitt, R. A. (1973). Identification of dacitic tephra by activation analysis of their primary mineral phenocrysts. Quaternary Research 3, 307-315.

Fryxell, R. (1965). Mazama and Glacier Peak volcanic ash layers: Relative ages. Science 147, 12881290.

Hoblitt, R. P., Crandell, D. R., and Mullineaux, D. R. (1980). Mount St. Helens eruptive behavior during the past 1,500 yr. Geology 8, 555-559.

Hopson, C. A. (1971). Eruptive sequence at Mount St. Helens, Washington. Geological Society of America Abstracts with Programs 3, 138. 
Hyde, J. H. (1973). "Late Quaternary Volcanic Stratigraphy, South Flank of Mount St. Helens, Washington." Ph.D. dissertation, University of Washington, Seattle.

Hyde, J. H. (1975). "Upper Pleistocene pyroclastic flow deposits and lahars south of Mount St. Helens volcano. Washington." U.S. Geological Survey Bulletin 1383-B.

Izett, G. A., Wilcox, R. E., Powers, H. A., and Desborough, G. A. (1970). The Bishop ash bed, a Pleistocene marker bed in the western United States. Quaternary Research 1, 121-132.

Lipman, P. W. (1965). "Chemical Composition of Glassy and Crystalline Volcanic Rocks." U.S. Geological Survey Bulletin 1201-D, D1-D24.

Mathewes, R. W., and Westgate, J. A. (1980). Bridge River tephra: Revised distribution and significance for detecting old carbon errors in radiocarbon errors in radiocarbon dates of limnic sediments in southern British Columbia. Canadian Journal of Earth Sciences 17, 1454-1461.

Mullineaux, D. R., Hyde, J. H., and Rubin, M. (1975). Widespread late glacial and postglacial tephra deposits from Mount St. Helens volcano, Washington. U.S. Geological Survey Journal of Research 3, 329-335.

Mullineaux. D. R., Wilcox, R. E., Ebaugh, W. F., Fryxell, R., and Rubin, M. (1978). Age of the last major scabland flood of the Columbia Plateau in Eastern Washington. Quaternary Research 10, 171-180.

Okazaki, R., Smith, H. W., Gilkeson, R. A., and Franklin, J. (1972). Correlation of West Blacktail ash with pyroclastic layer T from the 1800 A.D. eruption of Mount St. Helens. Northwest Science 46, 7789.

Porter, S. C. (1978). Glacier Peak tephra in the North Cascade Range, Washington: Stratigraphy, distribution, and relationship to late-glacial events. Quaternary Research 10, 30-41.

Powers, H. A., and Wilcox, R. E. (1964). Volcanic ash from Mount Mazama (Crater Lake) and from Glacier Peak. Science 144, 1334-1336. 
Randle, K., Goles, G. G., and Kittleman, L. R. (1971). Geochemical and petrological characterization of ash samples from Cascade Range volcanoes. Quaternary Research 1, 261-282.

Sarna-Wojcicki, A. M., Meyer, C. E., Russell, P. C., and Woodward, M. (1980). Chemical correlation and fission-track age dating of late Cenozoic tephra units in northern California, Oregon, Washington, and western Nevada. A presentation at the Cascade Conference, Feb. 19-20, 1980, Menlo Park, Calif.

Smith, D. G. W., and Westgate, J. A. (1969). Electron probe technique for characterizing pyroclastic deposits. Earth and Planetary Science Letters 5, 313-319.

Smith, H. W., Okazaki, R., and Knowles, C. R. (1977). Electron microprobe analysis of glass shards from tephra assigned to set W, Mount St. Helens, Washington. Quaternary Research 7, 202-217.

Westgate, J. A. (1977). Identification and significance of late Holocene tephra from Otter Creek, southern British Columbia and localities in west-central Alberta. Canadian Journal of Earth Sciences 14, 2593-2600.

Westgate, J. A., and Fulton, R. J. (1975). Tephro-stratigraphy of Olympia interglacial sediments in south-central British Columbia, Canada. Canadian Journal of Earth Sciences 12, 489-502.

Westgate, J. A., and Evans, M. E. (1978). Compositional variability of Glacier Peak tephra and its stratigraphic significance. Canadian Journal of Earth Sciences 15, 1554-1567.

Westgate, J. A., Christiansen, E. A., and Boellstorff, J. D. (1977). Wascana Creek ash (Middle Pleistocene) in southern Saskatchewan: Characterization, source, fission track age, paleomagnetism and stratigraphic significance. Canadian Journal of Earth Sciences 14, 357-374. 
Figure 1:

\begin{tabular}{|c|c|c|c|c|}
\hline Mineralogy & Set & & $\begin{array}{c}\text { Radiocarbon } \\
\text { (14 Cate Years B.P.) }\end{array}$ & $\begin{array}{c}\text { Sample } \\
\text { No. }\end{array}$ \\
\hline hy. hb & v & $\overline{w n}$ & $-1150 \pm 200$ & W-2993 \\
\hline ol, hy, aug & & & $\begin{array}{r}1620 \pm 200 \\
2200 \pm 250 \\
-2460 \pm 200 \\
2580 \pm 250\end{array}$ & $\begin{array}{l}w-2990 \\
w-2923 \\
w-1394 \\
w-2529\end{array}$ \\
\hline hy, hb & & & $\left\{\begin{array}{l}2930 \pm 250 \\
-2960 \pm 250 \\
-3350 \pm 250\end{array}\right.$ & $\begin{array}{l}w-2829 \\
w-2675 \\
w-2549\end{array}$ \\
\hline $\mathrm{hb}, \mathrm{cm}$ & & $\gamma_{n}$ & $-3510 \pm 230$ & $w-1752$ \\
\hline $\mathrm{hb}, \mathrm{cm}(\mathrm{bi})$ & & $x$ & $-3900 \pm 250$ & $w-2677$ \\
\hline$m y_{1} n b$ & & & $\begin{array}{l}-8300 \pm 350 \\
-8900 \pm 300\end{array}$ & $\begin{array}{l}W-2587 \\
w-2991\end{array}$ \\
\hline & & $\cos \theta$ & $\begin{array}{r}11.700 \pm 400 \\
-12,110 \pm 375 \\
-11.900 \pm 300\end{array}$ & $\begin{array}{l}W-2832 \\
W-2868 \\
w-2860\end{array}$ \\
\hline $\mathrm{cm}_{\mathrm{L}}$ & & 5 & $-13.130 \pm 350$ & $w-2983$ \\
\hline
\end{tabular}

FIG. 1. Diagrammatic section showing stratigraphic units exposed on the northern and eastern slopes of Mount St. Helens (previous to the 1980 eruptions). Layer $\mathrm{Wn}$ is dated at $\sim 450 \mathrm{yr}$ B.P. by tree-ring counts (Crandell, 1971). Data taken from Crandell and Mullineaux (1973), Mullineaux et al. (1975, 1978), and Hyde (1975). Key; ol = olivine, hy = hypersthene, $\mathrm{cm}$ - cummingtonite, hb - hornblende, bi - biotite, aug $=$ augite, ()$=$ in minor abundance. 
Figure 2:



FIG. 2. $\mathrm{Ca}-\mathrm{Fe}-\mathrm{K}$ ratios in glasses from various Cascade tephras: Glacier Peak (GP), the climactic eruption of Mount Mazama (MAZ), Bridge River tephra (BR), and Mount St. Helens tephra units T, W, Y, J, So (open circle), Sg (solid circle), Mm (open square), Mp (solid square). Data from Smith and Westgate (1969), Smith et al. (1977), Mullinaux et al. (1978), and Westgate and Evans (1978). 
Figure 3:

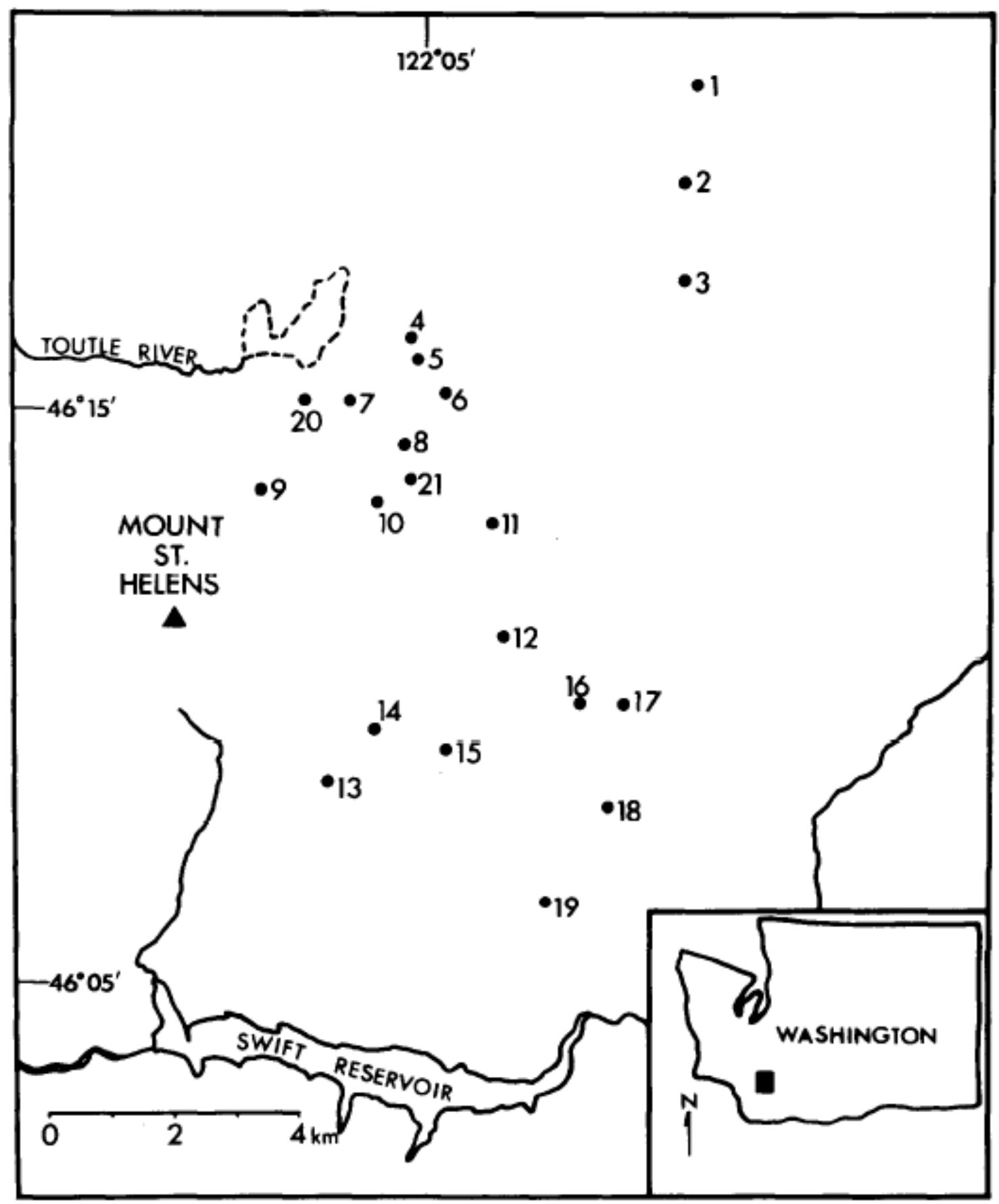

FIG. 3. Sample location map (Table 1). Dashed line indicates Spirit Lake's boundary before the May 18,1980 , eruption. 
Table 1:

TABLE 1. Sample Location Descriptions

\begin{tabular}{|c|c|c|c|}
\hline $\begin{array}{l}\text { Location } \\
\text { No. }\end{array}$ & Description & Sample No. & Unit \\
\hline 1 & $\begin{array}{l}\mathrm{NW} 1 / 4 \mathrm{SW} 1 / 4, \text { Sec. } 17, \mathrm{~T}, 10 \mathrm{~N} ., \mathrm{R} .7 \mathrm{E} . ; \\
\text { roadeut, west side of Road } 125\end{array}$ & $\begin{array}{l}\text { DS- } 53 \\
\text { DS } 54\end{array}$ & $W_{n}$ \\
\hline \multirow[t]{2}{*}{2} & \multirow{2}{*}{$\begin{array}{l}\mathrm{NE} 1 / 4 \mathrm{SE} 1 / 4, \mathrm{Sec} .30, \mathrm{~T} .10 \mathrm{~N} ., \mathrm{R} .7 \mathrm{E} . ; \\
\text { roadcut, east side of Road } 125\end{array}$} & $\begin{array}{l}\text { DS-54 } \\
\text { DS-51 }\end{array}$ & $\begin{array}{l}Y n \\
W n\end{array}$ \\
\hline & & DS-52 & $\mathrm{Yn}$ \\
\hline 3 & $\begin{array}{l}\mathrm{NE}^{1 / 4} \mathrm{SE} 1 / 4, \text { Sec. } 6 \text {, T. } 9 \text { N., R. } 7 \text { E.: } \\
\text { roadcut, east side of Road } 125\end{array}$ & DS- 50 & $W_{n}$ \\
\hline 4 & $\begin{array}{l}\mathrm{NE}_{1 / 4}^{1 /} \mathrm{SW}_{1 / 4} \mathrm{SW} 1 / 4, \text { Sec. } 8, T .9 \mathrm{~N} ., \mathrm{R} .6 \mathrm{E} \text {.; } \\
\text { roadcut, east side of Road } 100\end{array}$ & DS-45 & $\mathrm{Wn}$ \\
\hline 5 & $\begin{array}{l}\mathrm{SW}_{1 / 4} \mathrm{NE}^{1 / 4} \mathrm{NW} / 1 / 4 \text {, Sec. } 17, \mathrm{~T} .9 \mathrm{~N} . \text {. R. } 6 \mathrm{E} \text {; } \\
\text { roadcut, north side of Road } \mathrm{N} 92\end{array}$ & DS-60 & Wn \\
\hline \multirow[t]{3}{*}{6} & \multirow{3}{*}{$\begin{array}{l}\mathrm{SE}^{1} / 4 \mathrm{SE} 1 / 4 \mathrm{SE} 1 / 4, \text { Sec. } 17, \text { T. } 9 \text { N., R. } 6 \text { E.; } \\
\text { roadcut, Road N930 }\end{array}$} & DS-57 & Wn \\
\hline & & DS-59 & $\mathrm{Ye}$ \\
\hline & & DS-58 & $\mathrm{Yn}$ \\
\hline \multirow[t]{3}{*}{7} & \multirow{3}{*}{$\begin{array}{l}\text { NW1/4 NE } 1 / 4 \text { NE1/4, Sec. } 24, \text { T. } 9 \text { N., R. } 5 \text { E.: } \\
\text { roadcut, north side of Road } 100\end{array}$} & $\mathrm{SH}-4$ & $\mathrm{Wn}$ \\
\hline & & SH-5 & Wn \\
\hline & & SH-6 & Wn \\
\hline \multirow[t]{2}{*}{8} & \multirow{2}{*}{$\begin{array}{l}\text { SE1/4 SE1/4 SE1/4, Sec. } 19, \text { T. } 9 \text { N.. R. } 6 \text { E.; } \\
\text { toadcul, west side of Rual N92 }\end{array}$} & DS-11 & Wn \\
\hline & & D3-13 & Yn \\
\hline 9 & $\begin{array}{l}\mathrm{SE}_{1 / 4} \mathrm{SE} 1 / 4 \mathrm{SE} 1 / 4 \text {, Sec. } 27, \text { T. } 9 \text { N., R. } 5 \text { E.; } \\
\text { timberline viewpoint }\end{array}$ & DS-40 & $W n$ \\
\hline 10 & SE1/4 NE/4 NW/4, Sec, 31, T, $9 \mathrm{~N}_{1,}, \mathrm{R}, 6 \mathrm{E}$, & DS-15 & Yn \\
\hline \multirow[t]{2}{*}{11} & \multirow{2}{*}{$\begin{array}{l}\text { SE1/ NE1/4 SE1/4, Sec. 33, T. } 9 \text { N., R. } 6 \text { E.; } \\
\text { roadcut, east side of Road N930 }\end{array}$} & DS-55 & We \\
\hline & & DS-56 & $\mathrm{Ye}$ \\
\hline \multirow[t]{2}{*}{12} & \multirow{2}{*}{  } & DS- 19 & We \\
\hline & & DS-20 & $\mathrm{Ye}$ \\
\hline \multirow[t]{2}{*}{13} & \multirow{2}{*}{$\begin{array}{l}\text { SE1/4 NE1/4 NE1/4, Sec. 36, T. } 8 \text { N., R. } 5 \text { E.; } \\
\text { roadcut, north side of Road N83 }\end{array}$} & DS-30 & We \\
\hline & & DS-31 & $\mathrm{Ye}$ \\
\hline 14 & $\begin{array}{l}\mathrm{NE}^{1 / 4} \mathrm{NW} 1 / 4 \mathrm{NE} 1 / 4, \text { Sec. } 30, \text { T. } 8 \mathrm{~N} ., \text { R. } 6 \text { E.: } \\
\text { Streamcut exposure on east side of Pine } \\
\text { Creek }\end{array}$ & DS-34 & We \\
\hline 15 & $\begin{array}{l}\mathrm{NE}^{1 / 4} \text { NE1/4 SE1/4, Sec. } 29, \text { T. } 8 \text { N., R. } 6 \text { E.: } \\
\text { roadcut, east side of Road N833 }\end{array}$ & DS-36 & $\mathrm{Ye}$ \\
\hline 16 & $\begin{array}{l}\text { SW1/4 SE1/4 NE1/4, Sec. } 23, \text { T. } 8 \text { N., R. } 6 \text { E.; } \\
\text { roadcut, east side of Road N917 }\end{array}$ & DS-26 & $\mathrm{Ye}$ \\
\hline 17 & $\begin{array}{l}\mathrm{SW} 1 / 4 \mathrm{NE} / 1 / 4 \text {, Sec. } 25, \text { T. } 8 \text { N., R. } 6 \text { E.; } \\
\text { roadcut, east side of Road } 125\end{array}$ & DS-48 & $\mathrm{Ye}$ \\
\hline \multirow[t]{2}{*}{18} & \multirow{2}{*}{$\begin{array}{l}\mathrm{SW}^{1 / 4} \mathrm{NW} 1 / 4 \mathrm{SE} 1 / 4, \mathrm{Sec}, 36, \text { T. } 8 \mathrm{~N} \text {., R. } 6 \text { E.: } \\
\text { roadcut, east side of Road } 125\end{array}$} & DS-47 & We \\
\hline & & DS-46 & $\mathrm{Ye}$ \\
\hline 19 & $\begin{array}{l}\mathrm{NW}^{1 / 4} \mathrm{SW} 1 / 4 \text { NW1/4, Sec. 11, T. } 7 \text { N., R. } 6 \text { E.; } \\
\text { roadcut, north side of N833 }\end{array}$ & DS-38 & $\mathrm{Ye}$ \\
\hline 20 & $\begin{array}{l}\mathrm{SW}^{1 / 4} \mathrm{NW}^{1 / 4} \mathrm{NW} 1 / 4, \mathrm{Sec} .24, \mathrm{~T} .9 \mathrm{~N} ., \text { R. } 5 \text { E.; } \\
\text { roadcut, west side of Road } 100\end{array}$ & DS-44 & Yn \\
\hline 21 & $\begin{array}{l}\text { NW1/4 SE1/4 SE } 1 / 4 \text {, Sec. } 13, \text { T. } 9 \text { N., R. } 5 \text { E.; } \\
\text { roadcut, west side of Road } 100\end{array}$ & SH-17 & $\mathrm{Ye}$ \\
\hline
\end{tabular}


Table 2:

Table 2. Modal Proportions for Heavy Mineral Separates ${ }^{\alpha}$

\begin{tabular}{cccccc}
\hline Unit & Sample & Hypersthene & Hornblende & Cummingtonite & Opaques \\
\hline We & DS-30 & $71 \pm 5$ & $15 \pm 2$ & - & $14 \pm 2$ \\
We & DS-55 & $75 \pm 5$ & $8 \pm 2$ & - & $17 \pm 2$ \\
We & DS-47 & $82 \pm 5$ & $5 \pm 1$ & - & $13 \pm 2$ \\
We & DS-19 & $72 \pm 5$ & $8 \pm 2$ & - & $20 \pm 3$ \\
We & DS-47 & $82 \pm 5$ & $2 \pm 1$ & - & $9 \pm 2$ \\
Wn & DS-50 & $69 \pm 5$ & $14 \pm 2$ & - & $17 \pm 2$ \\
Wn & DS-51 & $72 \pm 5$ & $9 \pm 2$ & - & $19 \pm 2$ \\
Wn & DS-60 & $61 \pm 4$ & $19 \pm 3$ & - & $16 \pm 3$ \\
Wn & DS-40 & $72 \pm 4$ & $12 \pm 2$ & - & $16 \pm 2$ \\
Wn & DS-45 & $73 \pm 4$ & $11 \pm 2$ & - & $19 \pm 2$ \\
Wn & DS-57 & $66 \pm 5$ & $15 \pm 2$ & - & $10 \pm 2$ \\
Wn & SH-4 & $75 \pm 5$ & $15 \pm 2$ & - & $17 \pm 2$ \\
Wn & SH-5 & $72 \pm 5$ & $11 \pm 2$ & - & $14 \pm 2$ \\
Wn & SH-6 & $78 \pm 5$ & $8 \pm 2$ & - & $13 \pm 1$ \\
Wn & DS-11 & $75 \pm 5$ & $12 \pm 1$ & $37 \pm 3$ & $45 \pm 4$ \\
Ye & SH 17 & - & $18 \pm 2$ & $35 \pm 4$ & $32 \pm 4$ \\
Ye & DS-56 & - & $23 \pm 3$ & $45 \pm 4$ & $16 \pm 2$ \\
Ye & DS-48 & - & $22 \pm 3$ & $55 \pm 4$ & $34 \pm 3$ \\
Ye & DS-46 & - & $29 \pm 3$ & $33 \pm 3$ & $13 \pm 2$ \\
Ye & DS-59 & - & $33 \pm 3$ & $58 \pm 4$ & $49 \pm 4$ \\
Ye & DS-38 & - & $29 \pm 3$ & $33 \pm 3$ & $47 \pm 4$ \\
Ye & DS-20 & - & $18 \pm 2$ & $29 \pm 3$ & $47 \pm 4$ \\
Ye & DS-31 & - & $23 \pm 3$ & $34 \pm 3$ & $45 \pm 4$ \\
Ye & DS-36 & - & $19 \pm 2$ & $26 \pm 3$ & $66 \pm 5$ \\
Yn & DS-13 & - & $27 \pm 3$ & $18 \pm 2$ & $36 \pm 3$ \\
Yn & DS-54 & - & $37 \pm 3$ & $16 \pm 2$ & \\
Yn & DS-58 & - & $33 \pm 3$ & $18 \pm 2$ & \\
Yn & DS-44 & - & & & \\
\hline
\end{tabular}

a Specific gravity $>2.9672$, the fraction of $100-150$ mesh size was analyzed $(2.75-3.25 \phi$ units). More than 300 grains were counted in each sample. Uncertainties given are one standard deviation estimated from counting statistics. 
Figure 4:

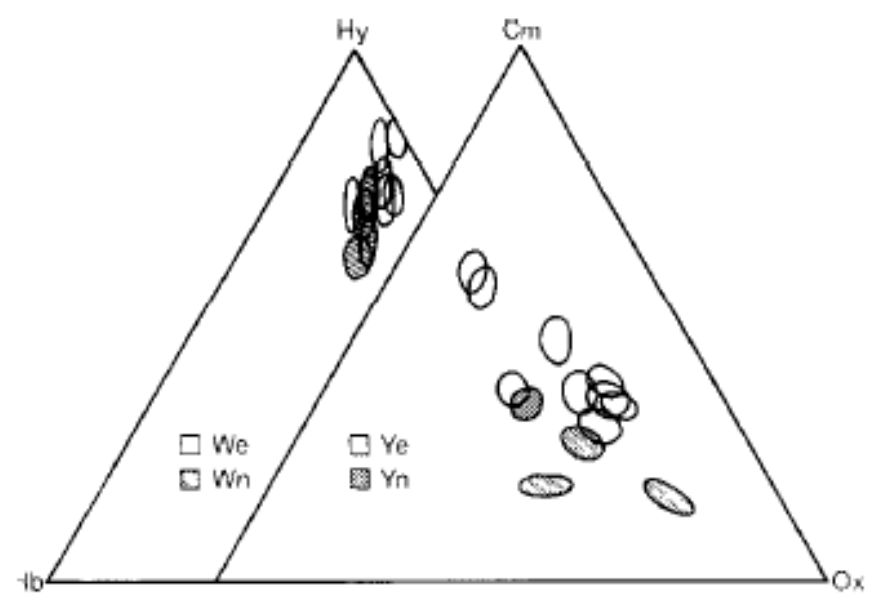

Fig. 4. Hypersthene-hornblende- $\mathrm{Fe}-\mathrm{Ti}$ oxide and cummingtonite-hornblende- $\mathrm{Fe}-\mathrm{Ti}$ oxide abundances for tephra sets W and Y, respectively. For each sample, the modal abundance and the uncertainty due to counting statistics are plotted.

Figure 5:

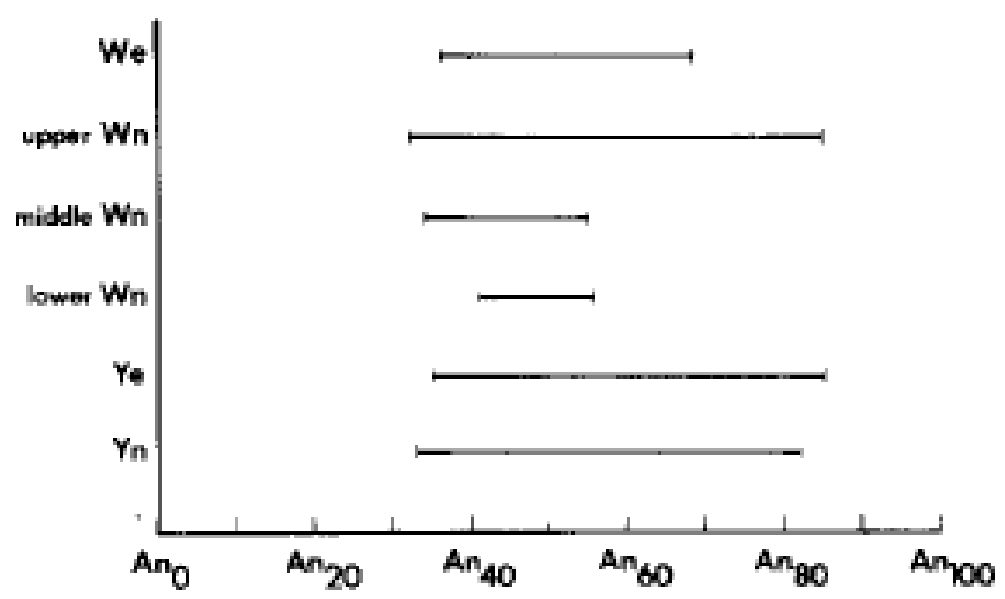

FIG. 5. Anorthite content in plagioclases in units Ye, Yn, We, and Wn. 
Table 3:

TABLE 3. Representative Analyses of Orthopytoxene

\begin{tabular}{|c|c|c|c|c|c|}
\hline Sample: & $\begin{array}{c}\text { We } \\
\text { DS-55 }\end{array}$ & $\begin{array}{c}\text { We } \\
\text { DS-45 }\end{array}$ & $\begin{array}{l}\text { Wn } \\
\text { SH-6 }\end{array}$ & $\begin{array}{l}\text { Wn } \\
\text { SH-5 }\end{array}$ & $\begin{array}{c}\text { Glacier peak } \\
{[\text { mean }(\sigma)]^{b}}\end{array}$ \\
\hline $\mathrm{SiO}_{2}$ & 50.9 & 50.8 & 51.2 & 51.9 & $54.23(0.36)$ \\
\hline $\mathrm{TiO}_{2}$ & 0.09 & 0.09 & 0.11 & 0.20 & $0.14(0.04)$ \\
\hline $\mathrm{Al}_{2} \mathrm{O}_{3}$ & 1.36 & 0.66 & 0.72 & 1.38 & $0.85(0.32)$ \\
\hline$\sum \mathrm{FeO}$ & 25.5 & 27.6 & 27.9 & 25.3 & $20.30(0.36)$ \\
\hline $\mathrm{MnO}$ & 0.64 & 0.75 & 0.80 & 0.66 & $1.05(0.10)$ \\
\hline $\mathrm{MgO}$ & 21.4 & 18.2 & 18.6 & 19.9 & $22.73(0.33)$ \\
\hline $\mathrm{CaO}$ & 0.78 & 0.86 & 0.85 & 1.13 & $0.86(0.10)$ \\
\hline $\mathrm{Na}_{2} \mathrm{O}$ & n.d. ${ }^{e}$ & n.d. & n.d. & n.d. & $0.01(0.01)$ \\
\hline $\mathrm{K}_{2} \mathrm{O}$ & n.d. & n.d. & n.d. & n.d. & $0.04(0.01)$ \\
\hline Sum & 100.67 & 98.96 & 100.18 & 100.47 & 100.21 \\
\hline \multicolumn{6}{|c|}{ Number of cations on the basis of six oxygens } \\
\hline $\mathrm{Si}$ & 1.923 & 1.971 & 1.964 & 1.958 & 1.998 \\
\hline $\mathrm{Ti}$ & 0.003 & 0.003 & 0.003 & 0.006 & 0.004 \\
\hline $\mathrm{Al}^{\mathrm{IV}}$ & 0.060 & 0.029 & 0.032 & 0.042 & 0.002 \\
\hline $\mathrm{Al}^{\mathrm{VI}}$ & 0.000 & 0.001 & 0.000 & 0.019 & 0.035 \\
\hline $\mathrm{Fe}$ & 0.805 & 0.897 & 0.896 & 0.798 & 0.625 \\
\hline Mn & 0.020 & 0.024 & 0.026 & 0.021 & 0.033 \\
\hline $\mathrm{Mg}$ & 0.201 & 1.050 & 1.060 & 1.116 & 1.248 \\
\hline $\mathrm{Ca}$ & 0.032 & 0.036 & 0.035 & 0.046 & 0.034 \\
\hline $\mathrm{Na}$ & - & - & - & - & 0.001 \\
\hline $\mathrm{K}$ & - & - & - & - & 0.002 \\
\hline \multicolumn{6}{|c|}{ Mole percentage } \\
\hline $\mathrm{Mg}$ & 58.9 & 53.0 & 53.2 & 56.9 & 65.4 \\
\hline $\mathrm{Fe}$ & 39.5 & 45.2 & 45.0 & 40.7 & 32.8 \\
\hline $\mathrm{Ca}$ & 1.6 & 1.8 & 1.8 & 2.4 & 1.8 \\
\hline
\end{tabular}

${ }^{n}$ Taken from Westgate and Evans (1978).

${ }^{b} \sigma=$ standard deviation.

"Not detected. 
Figure 6:

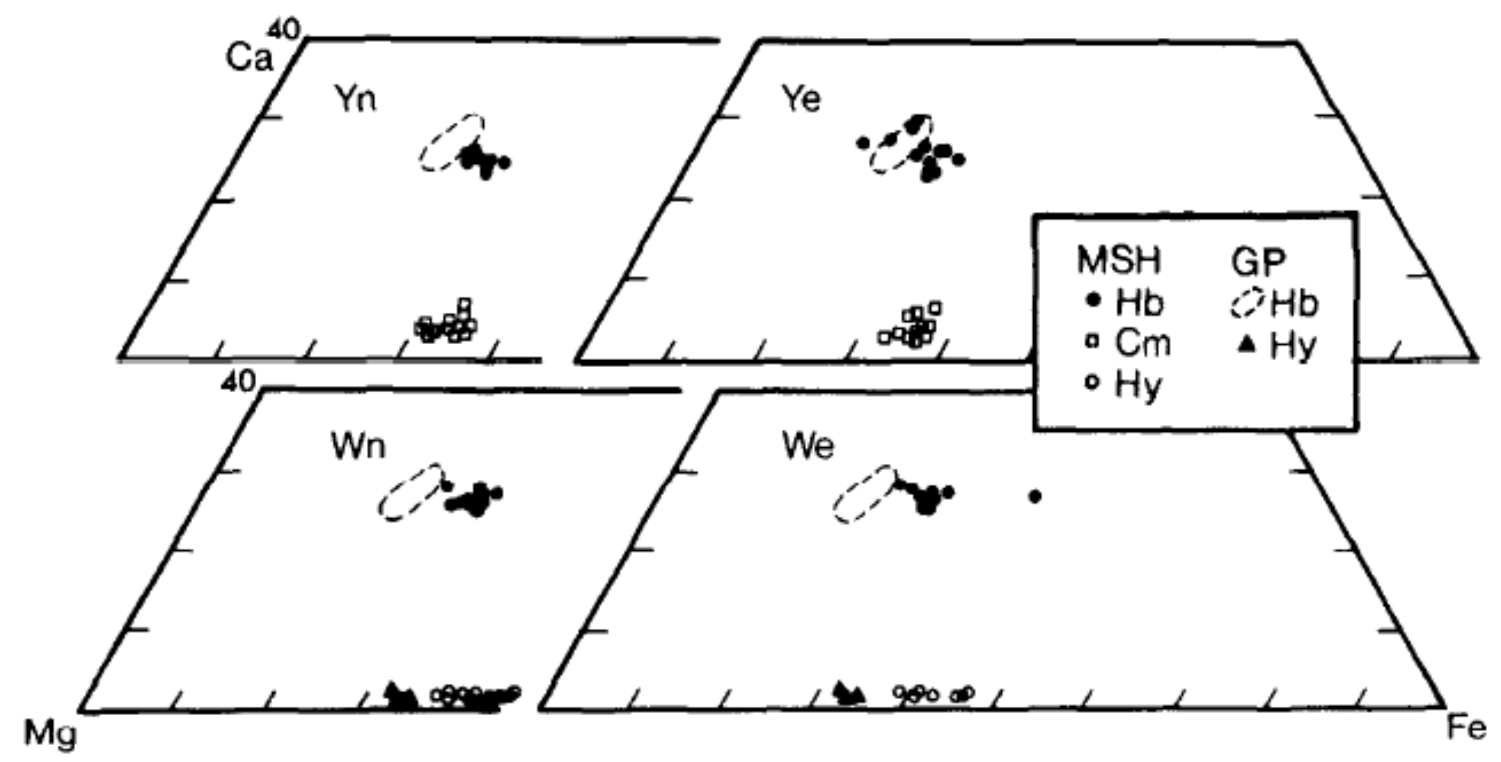

FIG. 6. Compositional ranges of ferromagnesian silicates in MSH Yn, Ye, Wn, and We, and Glacier Peak tephras. Abbreviations as in Figure 1. 
Table 4:

TAB́lE 4. Representative Analyses of CUMMINGTONite

\begin{tabular}{|c|c|c|c|c|}
\hline Sample: & $\begin{array}{c}\text { Yn } \\
\text { DS-13 }\end{array}$ & $\begin{array}{c}\text { Yn } \\
\text { DS-13 }\end{array}$ & $\begin{array}{c}\mathrm{Ye}^{a} \\
\text { SH-17 }\end{array}$ & $\begin{array}{c}\mathrm{Ye}^{b} \\
\mathrm{SH} \cdot 17\end{array}$ \\
\hline $\mathrm{SiO}_{2}$ & 54.7 & 52.3 & 54.5 & 53.8 \\
\hline $\mathrm{TiO}_{2}$ & 0.24 & 0.33 & 0.21 & 0.18 \\
\hline $\mathrm{Al}_{2} \mathrm{O}_{3}$ & 2.59 & 3.64 & 2.13 & 3.13 \\
\hline$\Sigma \mathrm{FeO}$ & 19.8 & 17.4 & 20.5 & 19.0 \\
\hline $\mathrm{MnO}$ & 0.68 & 0.56 & 0.74 & 0.67 \\
\hline $\mathrm{MgO}$ & 18.5 & 20.2 & 17.7 & 19.4 \\
\hline $\mathrm{CaO}$ & 1.49 & 2.23 & 1.94 & 1.48 \\
\hline $\mathrm{Na}_{2} \mathrm{O}$ & 0.29 & 0.65 & 0.17 & 0.32 \\
\hline $\begin{array}{l}\mathrm{K}_{2} \mathrm{O} \\
\quad \text { Sum }\end{array}$ & $\begin{array}{r}\text { n.d. } \\
98.29\end{array}$ & $\begin{array}{r}\text { n.d. } \\
97.31\end{array}$ & $\begin{array}{r}\text { n.d. } \\
97.89\end{array}$ & $\begin{array}{r}\text { n.d. } \\
97.98\end{array}$ \\
\hline \multicolumn{5}{|c|}{ Number of cations on basis of 23 oxygens } \\
\hline $\mathrm{Si}$ & 7.818 & 7.532 & 7.864 & 7.701 \\
\hline $\mathrm{Ti}$ & 0.026 & 0.036 & 0.023 & 0.019 \\
\hline Al & 0.436 & 0.618 & 0.362 & 0.528 \\
\hline $\mathrm{Fe}$ & 2.367 & 2.096 & 2.462 & 2.275 \\
\hline $\mathrm{Mn}$ & 0.082 & 0.068 & 0.090 & 0.081 \\
\hline $\mathrm{Mg}$ & 3.940 & 4.355 & 3.806 & 4.139 \\
\hline $\mathrm{Ca}$ & 0.228 & 0.344 & 0.300 & 0.227 \\
\hline $\mathrm{Na}$ & 0.080 & 0.181 & 0.048 & 0.089 \\
\hline \multicolumn{5}{|c|}{ Mole percentage } \\
\hline $\mathrm{Mg}$ & 60.3 & 64.1 & 57.9 & 62.3 \\
\hline $\mathrm{Fe}$ & 36.2 & 30.8 & 37.9 & 34.3 \\
\hline $\mathrm{Ca}$ & 3.5 & 5.1 & 4.6 & 3.4 \\
\hline
\end{tabular}

" Cure of discrete cummingtunite phenucryst.

- Rim of grain of previous analysis. 
Table 5:

TABLE 5. Refresentative ANalyses of Hornblende

\begin{tabular}{|c|c|c|c|c|c|c|c|c|c|c|c|c|}
\hline & $\mathrm{We}$ & $\mathrm{We}$ & We & $W_{n}$ & $W n$ & $W_{n}$ & $\mathrm{Ye}$ & $\mathrm{Ye}$ & Yc & Yn & $Y_{n}$ & $\mathrm{Yn}$ \\
\hline $\mathrm{SiO}_{2}$ & 40.6 & 42.5 & 45.2 & 41.2 & 42.5 & 44.8 & 42.7 & 44.9 & 47.1 & 49.3 & 44.0 & 48.2 \\
\hline $\mathrm{TiO}_{2}$ & 2.76 & 3.00 & 1.62 & 2.45 & 2.81 & 1.86 & 2.03 & 1.20 & 0.85 & 0.67 & 1.81 & 0.87 \\
\hline $\mathrm{Al}_{2} \mathrm{O}_{3}$ & 14.5 & 10.3 & 7.97 & 13.8 & 10.4 & 8.82 & 13.8 & 10.2 & 9.27 & 7.68 & 12.2 & 9.46 \\
\hline$\Sigma \mathrm{FeO}$ & 12.6 & 16.1 & 15.9 & 11.9 & 15.7 & 15.2 & 10.5 & 14.5 & 14.2 & 15.7 & 12.2 & 13.5 \\
\hline $\mathrm{MnO}$ & 0.11 & 0.22 & 0.11 & 0.16 & 0.24 & 0.25 & 0.11 & 0.34 & 0.40 & 0.39 & 0.22 & 0.26 \\
\hline $\mathrm{MgO}$ & 12.8 & 11.6 & 12.8 & 14.1 & 12.2 & 13.2 & 14.4 & 14.8 & 14.4 & 14.1 & 14.0 & 14.7 \\
\hline $\mathrm{CaO}$ & 10.8 & 10.6 & 10.8 & 10.9 & 10.8 & 10.6 & 10.7 & 9.25 & 9.31 & 8.57 & 10.3 & 9.70 \\
\hline $\mathrm{Na}_{2} \mathrm{O}$ & 2.22 & 2.18 & 2.22 & 2.44 & 2.13 & 1.82 & 2.05 & 1.72 & 1.30 & 1.17 & 1.75 & 1.20 \\
\hline $\mathrm{K}_{8} \mathrm{O}$ & 0.26 & 0.30 & 0.26 & 0.25 & 0.30 & 0.25 & 0.27 & 0.19 & 0.15 & 0.20 & 0.23 & 0.15 \\
\hline Sum & 96.65 & 96.80 & 96.88 & 97.20 & 97.08 & 96.80 & 96.56 & 97,10 & 96.98 & 97.78 & 96.71 & 98.04 \\
\hline \multicolumn{13}{|c|}{ Number of cations on basis of 23 oxygens } \\
\hline $\mathrm{Si}$ & 6.040 & $6.41 \overline{7}$ & 6.810 & 6.082 & 6.390 & 6.696 & 6.263 & 6.628 & 6.905 & 7.172 & 6.475 & 6.950 \\
\hline $\mathrm{Al}^{\mathrm{pv}}$ & 1.960 & 1.583 & 1.190 & 1.918 & 1.610 & 1.304 & 1.737 & 1.372 & 1.095 & 0.828 & 1.525 & 1.050 \\
\hline $\mathrm{Al}^{\text {ติ }}$ & 0.582 & 0.250 & 0.226 & 0.484 & 0.234 & 0.250 & 0.649 & 0.403 & 0.507 & 0.489 & 0.591 & 0.558 \\
\hline $\mathrm{Ti}$ & 0.309 & 0.341 & 0.184 & 0.272 & 0.318 & 0.209 & 0.224 & 0.133 & 0.094 & 0.073 & 0.200 & 0.094 \\
\hline $\mathrm{Fe}$ & 1.568 & 2.033 & 2.003 & 1.496 & 1.974 & 1.900 & 1.288 & 1.790 & 1.741 & 1.910 & 1.501 & 1.628 \\
\hline $\mathrm{Mn}$ & 0.014 & 0.028 & 0.031 & 0.020 & 0.031 & 0.032 & 0.014 & 0.043 & 0.050 & 0.048 & 0.027 & 0.032 \\
\hline $\mathrm{Mg}$ & 2.838 & 2.610 & 2.874 & 3.102 & 2.734 & 2.941 & 3.148 & 3.256 & 3.146 & 3.057 & 3.048 & 3.159 \\
\hline $\mathrm{Ca}$ & 1.722 & 1.715 & 1.711 & 1.724 & 1.740 & 1.698 & 1.682 & 1.463 & 1.463 & 1.336 & 1.627 & 1.499 \\
\hline $\mathrm{Na}$ & 0.640 & 0.638 & 0.494 & 0.698 & 0.621 & 0.527 & 0.583 & 0.492 & 0.370 & 0.330 & 0.499 & 0.335 \\
\hline K & 0.049 & 0.058 & 0.048 & 0.047 & 0.058 & 0.048 & 0.051 & 0.036 & 0.028 & 0.037 & 0.043 & 0.028 \\
\hline \multicolumn{13}{|c|}{ Mole percentage } \\
\hline $\mathrm{Mg}$ & 46.3 & 41.1 & 43.6 & 49.1 & 42.4 & 45.0 & 51.5 & 50.0 & 49.5 & 48.5 & 49.4 & 50.3 \\
\hline $\mathrm{Fe}$ & 25.6 & 32.0 & 30.4 & 23.6 & 30.6 & 29.0 & 21.0 & 27.5 & 27.4 & 30.3 & 24.3 & 25.9 \\
\hline $\mathrm{Ca}$ & 28.1 & 26.9 & 26.0 & 27.3 & 27.0 & 26.0 & 27.5 & 22.5 & 23.1 & 21.2 & 26.3 & 23.8 \\
\hline
\end{tabular}

Figure 7:

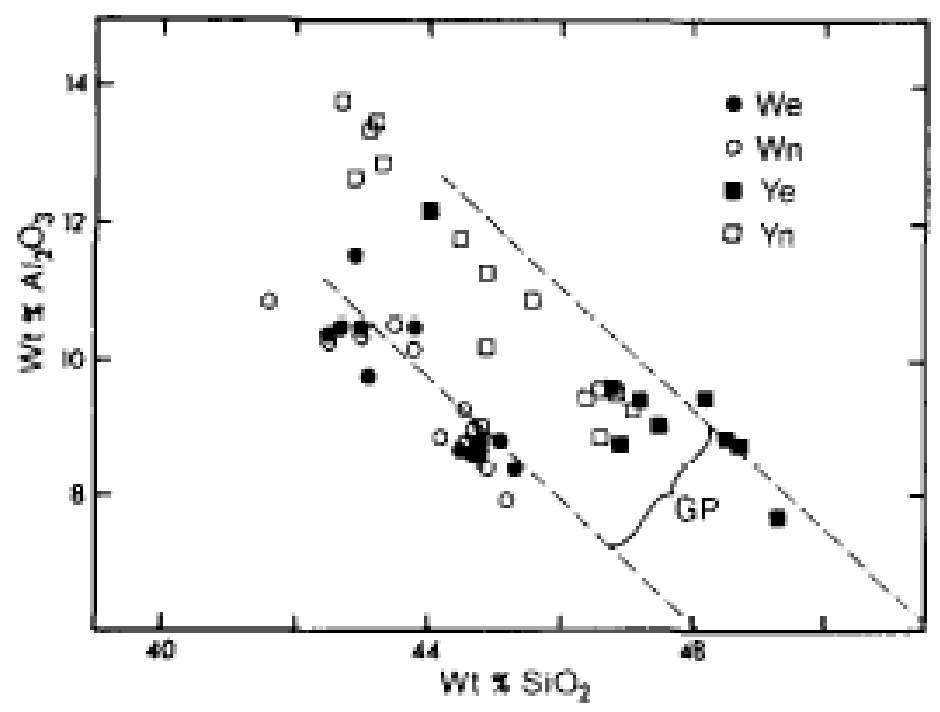

FIG. 7. Variation of $\mathrm{Al}_{2} \mathrm{O}_{3}$ (wt\%) with $\mathrm{SiO}_{2}$ (wt $\%$ ) in homblende in MSH tephras. The compositional range of hornblende in Glacier Peak tephra (Westgate and Evans, 1978) is indicated by the dashed boundaries. 
Table 6:

Table 6. Average Compositions of Iron-Titanium Oxides in Mount St. Helens tephras

\begin{tabular}{|c|c|c|c|c|}
\hline & We & Wn & $\mathrm{Ye}$ & $Y n$ \\
\hline & \multicolumn{4}{|c|}{ Magnetite } \\
\hline $\mathrm{SiO}_{2}$ & $0.24(0.05)^{a}$ & $0.23(0.06)$ & $0.12(0.04)$ & $0.12(0.04)$ \\
\hline $\mathrm{TiO}_{2}$ & $9.62(0.27)$ & $9.70(0.15)$ & $5.79(0.23)$ & $5.58(0.23)$ \\
\hline $\mathrm{Al}_{2} \mathrm{O}_{3}$ & $2.09(0.10)$ & $2.42(0.16)$ & $2.76(0.24)$ & $2.70(0.13)$ \\
\hline $\mathrm{FeO}$ & $37.6(0.2)$ & $38.0 \quad(0.2)$ & $34.3 \quad(0.3)$ & $34.1 \quad(0.3)$ \\
\hline $\mathrm{Fe}_{2} \mathrm{O}_{3}$ & $46.4 \quad(0.2)$ & $45.9 \quad(0.3)$ & $53.9(0.4)$ & $54.4 \quad(0.4)$ \\
\hline $\mathrm{MnO}$ & $0.36(0.03)$ & $0.35(0.03)$ & $0.36(0.02)$ & $0.34(0.03)$ \\
\hline $\mathrm{MgO}$ & $1.28(0.15)$ & $1.13(0.24)$ & $1.24(0.19)$ & $1.26(0.17)$ \\
\hline Sum & 97.59 & 97.73 & 98.47 & 98.50 \\
\hline$n^{b}$ & 20 & 34 & 33 & 19 \\
\hline \multirow[t]{2}{*}{ Mole\% Üsp } & 29.3 & 29.7 & 17.7 & 17.0 \\
\hline & \multicolumn{4}{|c|}{ limenite } \\
\hline $\mathrm{SiO}_{2}$ & $0.20(0.09)$ & $0.20(0.07)$ & $0.21(0.11)$ & $0.17(0.06)$ \\
\hline $\mathrm{TiO}_{2}$ & $44.8 \quad(0.6)$ & $44.9 \quad(0.5)$ & $39.3(1.2)$ & $39.9(0.7)$ \\
\hline $\mathrm{Al}_{2} \mathrm{O}_{3}$ & tr & tr & $0.33(0.14)$ & $0.25(0.11)$ \\
\hline $\mathrm{FeO}$ & $36.8 \quad(0.2)$ & $37.3 \quad(0.3)$ & $31.4 \quad(0.5)$ & $32.1 \quad(0.4)$ \\
\hline $\mathrm{Fe}_{2} \mathrm{O}_{3}$ & $14.0 \quad(0.1)$ & $13.7(0.1)$ & $24.9 \quad(0.4)$ & $24.2 \quad(0.3)$ \\
\hline $\mathrm{MnO}$ & $0.50(0.03)$ & $0.49(0.03)$ & $0.46(0.04)$ & $0.48(0.03)$ \\
\hline $\mathrm{MgO}$ & $1.81(0.16)$ & $1.58(0.22)$ & $2.09(0.28)$ & $1.98(0.25)$ \\
\hline Sum & 98.11 & 98.17 & 98.69 & 99.08 \\
\hline$n$ & 18 & 24 & 8 & 6 \\
\hline Mole\% Hem & 13.5 & 13.2 & 24.1 & 23.2 \\
\hline$T\left({ }^{\circ} \mathrm{C}\right)$ & 821 & 819 & 884 & 860 \\
\hline$-\log f_{\mathrm{O}_{2}}$ & 13.0 & 13.1 & 10.6 & 11.1 \\
\hline
\end{tabular}

- Standard deviation given in parentheses.

${ }^{\circ} \mathrm{n}=$ number of analyses. 
Table 7:

table 7. Average Compositions of Iron-Titanium Oxides in Pacific northwest Tephras

\begin{tabular}{|c|c|c|c|c|}
\hline & St. Helens " $\mathbf{Y}$ " & Glacier Peak & Bridge River & Mazama \\
\hline & \multicolumn{4}{|c|}{ Magnetite ${ }^{n}$} \\
\hline $\mathrm{SiO}_{2}$ & n.g. & $0.05(0.03)$ & n.g. & n.g. \\
\hline $\mathrm{TiO}_{2}$ & $5.85(0.29)$ & $6.15(0.06)$ & $7.56(0.26)$ & $8.66(0.36)$ \\
\hline $\mathrm{Al}_{2} \mathrm{O}_{3}$ & $2.61(0.09)$ & $2.23(0.06)$ & $1.87(0.08)$ & $2.09(0.17)$ \\
\hline $\mathrm{FeO}$ & $31.33(0.30)$ & $34.78(0.12)$ & $30.39(0.37)$ & $30.03(0.32)$ \\
\hline $\mathrm{Fe}_{2} \mathrm{O}_{3}$ & $58.54(0.85)$ & $54.98(0.03)$ & $57.38(0.77)$ & $55.68(0.64)$ \\
\hline $\mathrm{MnO}$ & $0.34(0.04)$ & $0.36(0.04)$ & $0.45(0.05)$ & $0.44(0.09)$ \\
\hline $\mathrm{MgO}$ & $1.18(0.10)$ & $1.32(0.04)$ & $1.99(0.18)$ & $2.40(0.23)$ \\
\hline Sum & 99.85 & 99.87 & 99.64 & 99.30 \\
\hline$n$ & 45 & 3 & 36 & 19 \\
\hline $\mathrm{FeO}^{\mathrm{r}}$ & 34.6 & 34.8 & 34.6 & 34.9 \\
\hline $\mathrm{Fe}_{2} \mathrm{O}_{3}{ }^{r}$ & 54.9 & 55.0 & 52.7 & 50.2 \\
\hline \multirow[t]{2}{*}{ Mole\% Olspr } & 176 & 183 & 223 & 25.6 \\
\hline & \multicolumn{4}{|c|}{ Ilmenite ${ }^{d}$} \\
\hline $\mathrm{SiO}_{2}$ & $0.10(0.04)$ & $0.05(0.05)$ & $0.26(0.04)$ & $0.16(0.09)$ \\
\hline $\mathrm{TiO}_{2}$ & $40.30(0.75)$ & $38.33(0.54)$ & $37.54(0.75)$ & $39.65(0.82)$ \\
\hline $\mathrm{Al}_{2} \mathrm{O}_{3}$ & $0.36(0.02)$ & $0.31(0.02)$ & $0.33(0.03)$ & $0.36(0.02)$ \\
\hline $\mathrm{FeO}$ & $32.94(0.66)$ & $30.65(0.55)$ & $29.37(0.85)$ & $30.36(0.52)$ \\
\hline $\mathrm{Fe}_{2} \mathrm{O}_{3}$ & $23.94(1.41)$ & $28.51(1.27)$ & $29.92(0.90)$ & $25.14(1.25)$ \\
\hline $\mathrm{MnO}$ & $0.38(0.03)$ & $0.38(0.05)$ & $0.36(0.11)$ & $0.38(0.03)$ \\
\hline $\mathrm{MgO}$ & $1.70(0.07)$ & $1.96(0.08)$ & $2.36(0.11)$ & $2.86(0.13)$ \\
\hline Sum & 99.72 & 100.19 & 100.14 & 98.91 \\
\hline$n$ & $8^{r}$ & 4 & $15^{\circ}$ & $21^{r}$ \\
\hline $\mathrm{FeO}^{r}$ & 32.9 & 30.7 & 29.5 & 30.5 \\
\hline $\mathrm{Fe}_{2} \mathrm{O}_{2} \mathrm{c}$ & 23.9 & 28.5 & 29.8 & 25.0 \\
\hline Mole $\% \mathrm{Hem}^{r}$ & 22.9 & 27.1 & 28.4 & 24.0 \\
\hline$T\left({ }^{\circ} \mathrm{C}\right)$ & 857 & 954 & 1019 & 966 \\
\hline$-\log f_{\mathrm{O}_{2}}$ & 11.2 & 9.3 & 8.4 & 9.6 \\
\hline
\end{tabular}

a Data for St. Helens Y, Bridge River, and Mazama tephras taken from Brewster and Barnett (1979). Data for Glacier Peak taken from Westgate and Evans (1978).

n.g. = not given.

r Recalculated values: see text for discussion.

"Taken from Mathewes and Westgate (1980).

- Each analysis is based on an average of ten grains. 
Figure 8:



a

Fig. 8. $\mathrm{MgO}$ and $\mathrm{TiO}_{2}$ and $\mathrm{Al}_{2} \mathrm{O}_{3}$ and $\mathrm{TiO}_{2}$ in titanomagnetites from $\mathrm{MSH}$ We, Wn, Ye, $\mathrm{Yn}$ (this study), Glacier Peak tephra (Westgate and Evans, 1978), Mazama ash and Bridge Kiver tephrara (Brewster and Barnett, 1979). Mean value $\pm 2 \sigma(\sigma=$ standard deviation) is plotted. Abbreviations as in Figure 1.

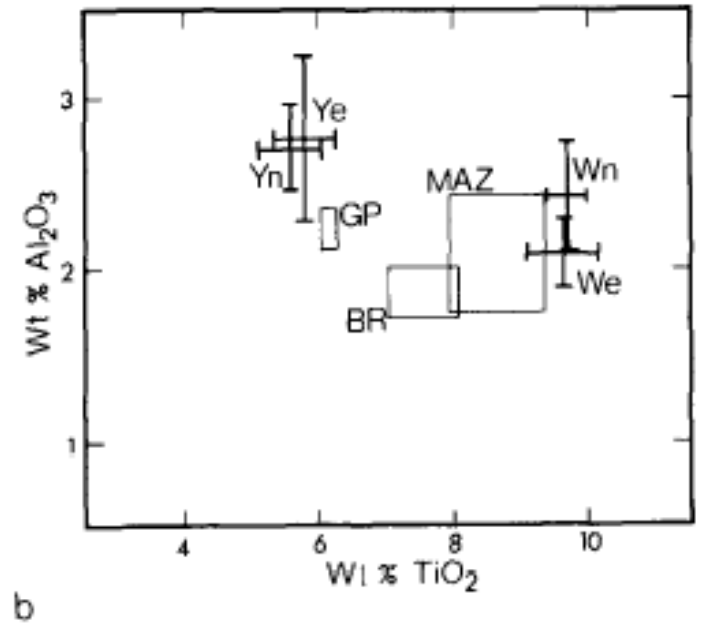

b 
Figure 9:



Fig. 9. Temperature vs $-\log f_{\mathrm{O}_{2}}$ for various Pacific Northwest tephras. The average values are plotted with error bars indicating a range of $\pm 25^{\circ} \mathrm{C}$ and $\pm 0.5 \log$ unit. " $\mathrm{Y} "$ represents $T-f_{\mathrm{O}_{2}}$ values derived using previously published analyses of $\mathrm{Fe}-\mathrm{Ti}$ oxides attributed to tephra set $\mathrm{Y}$ : other abbreviations as in Figure 1. 
Table 8:

Table 8. Characteristićs óf Selécted Pacific Northwestit 'Tephras

\begin{tabular}{|c|c|c|c|c|c|}
\hline \multirow[b]{2}{*}{ Unit } & \multirow{2}{*}{$\begin{array}{l}\text { Age } \\
\left({ }^{*} \mathrm{C} \text { yr }\right. \\
\text { B.P.) }\end{array}$} & \multirow{2}{*}{$\begin{array}{c}\text { Ferromagnesian } \\
\text { silicate } \\
\text { assemblage }^{\sigma}\end{array}$} & \multirow[b]{2}{*}{$\mathrm{Mg} \#^{D, c}$} & \multicolumn{2}{|c|}{ Ilmenite Composition ${ }^{e}$} \\
\hline & & & & $\begin{array}{l}\mathrm{TiO}_{2}(\mathrm{wt} \%) \\
{[\text { mean }(\sigma)]}\end{array}$ & $\begin{array}{l}\text { Hematite } \\
\text { (mole\%) }\end{array}$ \\
\hline $\mathrm{Wc}$ & $>450^{t}$ & hy, hb & hy: $52-59$ & $44.8(0.6)$ & 13.5 \\
\hline Wn & $<1,150$ & hy, hb & hy: $53-64$ & $44.9(0.5)$ & 13.2 \\
\hline $\mathrm{Ye}$ & $>3,000^{d t}$ & hb, cm (hy) & $\mathrm{cm}: 57-64$ & $39.3(1.2)$ & 24.1 \\
\hline Yn & $<4,000$ & hb, cm (by) & $\mathrm{cm}: 60-65$ & $39.9(0.7)$ & 23.2 \\
\hline $\begin{array}{l}\text { Bridge } \\
\text { River }\end{array}$ & $-2500^{r}$ & hy, aug, hb (bi) & - & $37.54(0.75)$ & 28.4 \\
\hline $\begin{array}{r}\text { Glacier } \\
\text { Peak }\end{array}$ & $\sim 12,000$ & hy, hb & hy: $65-67$ & $38.33(0.54)$ & 27.1 \\
\hline Mazama & $\sim 6,600^{f}$ & aug, hy, hb & - & $39.65(0.82)$ & 24.0 \\
\hline
\end{tabular}

"Abbreviations for minerals as in Figure 1. Data from Powers and Wilcox (9164), Mullineaux el al. (1975), and Mathewes and Westgate (1980).

${ }^{\delta} \mathrm{Mg} \#=(\mathrm{Mg} /(\mathrm{Mg}+\mathrm{Fe})) \times 100$ (molar ratio).

' Compositional data for MSH tephras from this study; other data are from sources cited elsewhere. Mole percentage hematite and ulvospinel, temperature, and $-\log f_{\mathrm{O}_{2}}$ have been calculated in a similar manner for each unit as discussed in text.

${ }^{\circ}$ Mullineaux et al. (1975).

' Mathewes and Westgate (1980).

${ }^{f}$ Fryxell (1965).

TABLE 8-Continued

\begin{tabular}{|c|c|c|c|c|c|}
\hline \multicolumn{4}{|c|}{ Magnetite composition } & \multirow[b]{2}{*}{$\begin{array}{c}T \\
\left({ }^{\circ} \mathrm{C}\right)\end{array}$} & \multirow[b]{2}{*}{$-\log f_{O_{2}}$} \\
\hline $\begin{array}{l}\mathrm{TiO}_{2}(\mathrm{wt} \%) \\
{[\text { mean }(\sigma)]}\end{array}$ & $\begin{array}{c}\mathrm{Al}_{2} \mathrm{O}_{3}(\mathrm{wt} \%) \\
{[\text { mean }(\sigma)]}\end{array}$ & $\begin{array}{c}\mathrm{MgO}(\mathrm{wt} \%) \\
{[\operatorname{mean}(\sigma)]}\end{array}$ & $\begin{array}{l}\text { Olvospinel } \\
\text { (mole\%) }\end{array}$ & & \\
\hline $9.62(0.27)$ & $2.09(0.10)$ & $1.28(0.15)$ & 29.3 & $\sim 835$ & -13.0 \\
\hline $9.70(0.15)$ & $2.42(0.16)$ & $1.13(0.24)$ & 29.7 & $\sim 820$ & $\sim 13.1$ \\
\hline $5.79(0.23)$ & $2.76(0.24)$ & $1.24(0.19)$ & 17.7 & -880 & $\sim 10.6$ \\
\hline $5.58(0.23)$ & $2.70(0.13)$ & $1.26(0.17)$ & 17.0 & -860 & $\sim 11.1$ \\
\hline $7.56(0.26)$ & $1.87(0.08)$ & $1.99(0.18)$ & 22.3 & $\sim 1020$ & -8.4 \\
\hline $6.15(0.06)$ & $2.23(0.06)$ & $1.32(0.04)$ & 18.3 & $\sim 955$ & -9.3 \\
\hline $8.66(0.36)$ & $2,09(0.17)$ & $2.40(0.23)$ & 25.6 & -965 & -9.6 \\
\hline
\end{tabular}

